\title{
Perpetuating Nigerian Cultures in Musical Arts Education within the Threshold of Current Global Environment
}

\author{
Dan C. C. Agu*
}

\section{Abstract}

In the past, articulation of traditional musical arts offered the Nigerian child opportunity for demonstrating sense of belonging with his environment. Participation in traditional music unveiled to him, key aspects of socio-cultural expression and behavior that stimulated new levels of appreciation of his culture. The current trend in musical arts education has denied the child the great opportunity of acquiring basic local knowledge, attaining social, cultural, religious and cosmic awareness, which the western music practices, could not offer him. Our inadequacies in playing or singing our indigenous music and inability to identify the folk taxonomies of our traditional musical instruments are glaring. Research conducted in selected Primary Schools in Anambra State, Nigeria over a period of five years (2003 - 2008) has proved that the Nigerian child still has the capacity and ability to effectively perform the traditional music of his community with great enthusiasm and passion. This article suggests ways of reviving our musical roots by examining the society's attitude towards traditional music, restructuring the music curricula and retraining the music educators. It posits that only such appropriate measures could refocus and strengthen our musical arts delivery and put us on the right track towards making a bold statement in the current global setting.

http://dx.doi.org/10.4314/ujah.v13i2.1

\section{Introduction}

It had been earlier posited in Agu (2008) that music is the expression of man's deepest self and that its effect can be tremendously profound only when its scholarship has attained 
UJAH: Unizik Journal of Arts and Humanities Vol. 13 No 2, 2012

certain elements of originality and nationality. In the same vein, Miller (1972) opined that music, like other arts, is always part of a total culture both in time and in place. It is not autonomous. And music making, being a symbolic expression of social and cultural organization, reflects the values and the past and present ways of life of the human beings who create it. On this premise, Blacking, (1971) stated that it becomes undoubtedly clear that our indigenous music is humanly created and performed. It is positive and delivers enormous social and health values. Therefore it is highly cherished because it enlightens and culturally sensitizes the people, as well as provides spiritual experience and awareness. Nzewi (2003) concludes that musicianship in Africa that excludes shared human sentiments and social contexts for co-creativity in participation is diabolically conceived.

This discourse is concerned with critical appraisal of the import of musical arts education and practice in Nigeria during the pre-colonial and post colonial periods. My objective has been to emphasize the primacy of musical arts education and practice as a vital tool for perpetuating Nigerian cultures within the threshold of current global environment. The study reviews the advantages or gains of consistent advancement of musical arts education and practice in the Nigerian traditional societies in the past, and tries to compare it with what obtains in contemporary Nigeria today. It also evaluates the content and quality of musical arts education and learning in Nigerian schools, using ten selected Primary Schools from five Local Government Areas of Anambra State, Nigeria, as a case study.

The choice of primary schools was predicated on the conviction that reinstituting and perpetuating Nigerian culture through musical arts education and presentation at that level is most appropriate since music education in Nigerian cultures starts at a very tender age and develops with the child. Nzewi (2007) submitted that even in modern situation, classroom 
musical arts education could still play a major role in reinstituting and perpetuating Nigerian cultures.

\section{Music in the Pre-colonial Era}

The Nigerian traditional musical arts education and practice was holistic in approach. It involved learning to play instruments, dance, sing, mime and dramatize music. In most Nigerian cultures, the entire exercise was clearly indispensable to the proper promulgation of the activities of the communities. According to Agu (1989) it was a fascinating experience because it was directly associated with the social, cultural, religious and political systems and was preserved by tradition. Agu (1989). And in all its elements and applications, it has latent psychological, psychical and spiritualizing essence (Nzewi1980). The traditional communities ensured that the musical traditions so established were imbibed right from childhood. In addition to acquisition of musical skills and competence, the system also paid serious attention to character formation. Right from childhood the young Nigerian was guided through musical arts education to enculcate good behaviours, attitudes, speech, action and traditions that are considered necessary for the making of a person in his environment (Emeka, 2002).

There existed the village squares which served as recreational centres and open theatres where musical and dance activities, moonlight plays, wrestling matches and all sorts of gatherings, including meetings, took place. Entertainment, social and cultural activities were consistent, vibrant and well articulated. At a certain age among the Igbo of Nigeria, boys (between ten and fifteen) had perfected the art of constructing certain musical instruments like, slit wooden drums, miniature membrane drums, flutes, musical bows, whistles and so on. At this age too, virtually all adult instruments were recognized and known by their names. 


\section{Post-colonial Era}

The advent of the Islamic and Christian religion in Nigeria ushered in a new trend in musical arts education and practice. The establishment of churches and schools in southern Nigeria had adverse effects on traditional musical arts education and practice as prescribed by culture and tradition. Accoding to Ochrie and Emeka "these religions have millions of adherents and their systems of thoughtand art have been implanted into the systems of civilization holding sway in large swathes of the continent". (2003. 45)

Gradually, interest in traditional music and dance waned in preference to foreign music. The principle of slow absorption of musical experience through observation, imitation and active participation was subjugated by the new system which advocates teaching music through technique as against teaching technique through music, which the traditional system advocates.

The acceptance of western system of education culminated to emergence of white collar jobs, urbanization, migration to the cities and rural development which brought a lot of changes. Rural environments and communal affiliations became negatively affected by the new developments. Okafor, (1993) lamented that "the environment and situation have changed today, and we changed with it." The emergence of popular music caught the interest of both young and old. And the western classical music received the attention of the elite, especially those in the academia.

Many village squares which in the past served as entertainment and performance centres gave way to town halls and other developmental projects. Some aspects of musical arts education and practice virtually disappeared, and with their cultural heritage, too. People's attitude towards their tradition, culture and music changed. The well established system of musical arts education and practice gradually became jettisoned. Young boys and girls who in the past were 
conversant with indigenous musical practices, lost grip with the trends, so much so that they now could hardly sing the traditional songs or play the traditional instruments which were taken for granted in the past.

The Church and School never spared our traditional music. Its performance was prohibited and labelled satanic. Omibiyi noted that "the music curriculum in the schools at all levels was western oriented and the entire content of instruction was completely western-too simplistic and circumscribed "(1987). Regrettably, this situation has remained on ground even in contemporary Nigeria today.

\section{Musical Arts Education in Contemporary Nigerian Schools} In an attempt to investigate the mode of delivery of musical arts education and practice in Nigerian Primary Schools, ten schools in six Local Government Areas of Anambra State were chosen and monitored over a period of five years, (November 2003 - July 2008). The schools include:

- Nnamdi Azikiwe University Primary and Nursery School, Awka (Awka South LGA)

- Central School, Onitsha (Onitsha North L.G.A.)

- St. Paul's Primary and Nursery School (Awka South L.G.A.)

- St. Thomas' Primary School, Otolo Nnewi. (Nnewi South L.G.A.)

- All Saints Primary School, Onitsha. (Onitsha North L.G.A.)

- Gbughemobi Primary School, Obosi. (Idemili North L.G.A.)

- Community Primary School, Umuogali Oba. (Idemili South L.G.A.)

- Central School Enugu-Ukwu (Njikoka L.G.A.) 
UJAH: Unizik Journal of Arts and Humanities Vol. 13 No 2, 2012

- Central School Akpakaogwe, Ogidi (Idemili North L.G.A.)

- Community Primary School, Ojoto-Uno (Idemili South L.G.A.)

The selection of these schools was randomly done. It has been noted earlier that the choice of Primary Schools for this research was predicted on the conviction that reinstituting and perpetuating Nigerian culture through musical arts education and practice at this level is most appropriate since music education in Nigerian cultures start at a very tender age and develop with the child.

Musical activities in each of the selected schools were closely monitored over the five year period. And each school was visited at least, twice a year. During the first round of visitation, it was observed that only choral singing was approved as musical activity at the Primary School level in Anambra State. The singing periods appeared on the lesson time table on Mondays and Wednesdays as last periods of each of the days. There were just a few trained music teachers and most of the schools visited had none. For example, only four trained music teachers could be found in Idemili South Local Government Area where forty four (44) Primary Schools exist. None of the ten primary schools under study owned musical instruments, indigenous or western. None of the schools had any music text books or song books. In the most cases, the singing periods were not even utilized for that purpose, teachers often used the periods for making up their short falls in other subjects.

Further investigations revealed that the teachers lacked the basic knowledge to handle the singing classes. During the singing periods, pupils were gathered in one class and guided by one teacher to partake in an unorganized singing jamboree. In this process, pupils were encouraged to intone songs of their 
choice. It was also found that most of the songs intoned were English tunes, rhymes and religious songs used in Christian worship. This exercise was repeated in these schools year after year. Unfortunately, the methodology continuously failed to arouse the intellect of the child and enhance balanced behavior which makes positive impact on his senses.

The content of the Nigerian National Policy on Education (1998) states thus:

In order to encourage aesthetic, creative and musical activities, Government will make staff and facilities available for the teaching of creative arts, craft and music in primary school.

This policy implies that music is inclined as one of the core subjects to be taught in the Primary Schools to help inculcate aesthetic values in the Nigerian child. Also in its Cultural Policy (1988), The Nigerian Government sought to promote, preserve and present Nigerian music, dance and drama on video films, audio tapes, slides and in written forms. This Policy also advocates the application of local music and musical instruments as base in musical arts education and practice. These policies appear to be of good intent, but the pertinent question is this: how far has the government gone with their implementation? Could this policy be implemented; if yes, when? The basic facts are quite glaring and include the following:

- There is untrained manpower to ensure their proper execution

- The Primary schools are not provided with appropriate teaching and learning aids such as musical instruments, books, and other materials that would provide guidelines and core knowledge about Nigerian and African musical arts. 
UJAH: Unizik Journal of Arts and Humanities Vol. 13 No 2, 2012

- The music curricular at all levels of education consistently groom the young Nigerian on Western music sensibility

- The average adult Nigerian out there looks down on Nigerian indigenous music and musical practices and regard them as something exclusively reserved for the "uneducated" and "unenlightened" citizens.

- The government has not shown full commitment to establishing an institution for genuine development of the citizenry in knowledge of musical arts education with cultural details.

\section{Experimentation and Findings}

The classroom based music education was deficient. It has never offered the Nigerian child the opportunity to acquire basic local knowledge. It never aroused in him enthusiasm and passion, and it never created appropriate environment for the development of the creative instinct in the child. The process created the impression that the Nigerian child had completely lost grip with the relevance of Nigerian traditional backgrounds in musical arts practice. But when the African system of delivery informed by indigenous knowledge was introduced by the researcher, the pupils brightened up with smiles and vibrant responses. The introduction of the indigenous systems of learning encouraged the pupils to imbibe musical knowledge through real experiences which led them to think and act musically.

As first step, a range of percussion instruments including rhythmic and melodic varieties, and flute were assembled by the researcher. Secondly, a range of indigenous songs were selected. They included songs on morals, sex education, civic responsibility and folktale songs. The singing was blended with instrument accompaniment and free medley dance pattern to produce good results. The pupils practically grasped the musical concept as they proceeded from the known 
to the unknown. In the process of learning the various musical acts, they experienced human sentiments and co-creativity in participation. While the exercise progressed, the pupils felt the impact of the indigenous music through its communicative power which triggered various types of responses in their bodies. Each time they performed, their spirits became elevated and they became emotional. Blacking (1973) had earlier observed that African music generates a tremendous motor behavior in all, irrespective of their sex and age. And Weman (1960) appreciates the fact that African traditional music captivates all participants and observers during performance because of what the form means to them in terms of human experience. Summing up these observations, Amamasi (2008), admits thus: "I actually believe in African music because I'm an African ... I believe Africa is rich, with rich culture and full of music."

For the vocal music, the technique was mainly antiphonal. The soloist(s) usually intoned the song and the chorus "received" it or responded. The chorus section was simple and consistent all the time while the soloist's section involved improvisation which was all the time guided through artistic features.

Handling a standardized dance requires a professional input. For this purpose therefore, the services of traditional experts were hired. It was a serious project which required much more time than what was approved by school curriculum. The following steps were taken to ensure its successful execution ${ }^{1}$.

- Agreement was reached with the head teachers, the music teachers and the pupils' parents and guardians on the need to schedule rehearsals occasionally after school.

- The rehearsals were broken into two, (group and sectional rehearsals). In sectional rehearsals, pupils 
UJAH: Unizik Journal of Arts and Humanities Vol. 13 No 2, 2012

were grouped under dance, instrumentation and vocals. This arrangement made the learning process easier and faster, since the teachers had less number of people to supervise and manage in each section. The group rehearsals were occasionally organized to assess and blend the achievements of the different sections.

- At the end of each rehearsal, be it sectional or group, there was evaluation period to access the outcome of each rehearsal.

During the choral and dance rehearsals, individual talents and capabilities of pupils were explored while adhering to the principle of communal participation, which ensures social bonding and psychological well being, as well as promoting self discovery and competence. As the teaching and learning process progressed, it was discovered that the continuous involvement of the pupils enforced their conformity to social norms.

Consequently, it made them aware and appreciative of their culture and roots, as well as sustained and enhanced the stability of our culture. The same methods of teaching and learning process were applied in the ten Primary Schools, and similar results were obtained though the rate of absorption of musical knowledge slightly differed as a result of logistics and other environmental and social problems. Nevertheless the responses have shown that the tendencies and powers of the Nigerian child could be developed in a satisfactory manner to himself and the community with the application of the Nigerian concept in musical arts education and practice.

\section{Recommendations}

The results of the experiments so far have confirmed the gains of articulated contemporary musical arts education as acquisition of basic local knowledge, attainment of social, cultural, religious and cosmic awareness. We therefore need to 
sustain this practice to enable us strengthen our musical arts delivery strategy for optimum gains in the current global setting.

We could only achieve this by genuinely taking the following steps:

- Developing the tendencies and powers of the Nigerian child through the re-introduction of traditional concept in musical arts education, learning and practice.

- Largely localizing music curricula in schools at all levels, with the needs, aspirations, values and trends of the communities well accommodated therein.

- The government should enforce the implementation of the National Policy on education by providing adequate staff and facilities for the teaching of creative arts, crafts and music in Primary Schools.

- Through the government's Cultural Policy on education, an enabling Nigerian human environment should be provided to encourage informal music education right from homes. This would serve as a vessel for integrating the child into his society and environment.

- To regain intellectual disposition towards Nigerian indigenous music, we need to evolve a new philosophy deriving from the cultural systems in re-educating and re-orientating the music educators in our schools.

- Contemporary Nigerian choral music composers whose compositions are informed by indigenous knowledge systems should engage in conceiving their musical compositions within the literary world of staff notation rather than the tonic solfa. Such exercise would enhance their availability and acceptance for global performance.

- The instrumental music composers should as well toe Nzewi's footsteps by adopting staff notation in their 
compositions to strike a balanced interest within the threshold of current global environment. The Nigerian government should see this as a golden opportunity and sincerely support massive production of Nigerian indigenous music in scores. This would promote acquisition of modern music educational skills among Nigerians, as well as popularize the music globally.

- Establishment of National movement for documentation of Nigerian music and cultures, including arts and other features in our natural environment, especially those that strongly impact on our cultural activities. This step would hopefully compel the Nigerian masses to participate in actualizing what Nzewi (2007) called the divine mandate of human musical arts mission as a potent mystical force.

\section{Conclusion}

This research set out to critically appraise the import of musical arts education in Nigeria over a period covering the pre-colonial and post colonial eras. The primary aim was to emphasize the value of musical arts heritage as a vital tool for perpetuating Nigerian cultures within the threshold of current global environment. In the process of achieving this aim, the gains of consistent advancement of musical arts education in Nigerian traditional setting was reviewed and compared with what obtains today. In this evaluation, musical practices in selected Primary Schools in Anambra State were scrutinized.

The findings led to the conclusions that the advent of colonialism introduced a new system of musical arts education contrary to the traditionally institutionalized system. The experiments carried out (though not exhaustive, having paid no attention to theoretical aspect), indicates that despite the poor handling of musical arts education in our schools, the Nigerian child still inhibits innate musical abilities and is cable of 
resurrecting them when adequately aroused. It also revealed that the traditional process of acquisition of musical skills does not generate stress. This research has strengthened the assertion that indigenous music plays a vital role in the process of cultural transmission and serves as a pivot on which the impact of education rotates in Nigerian communities. Nzewi (2007) has consistently maintained thus:

... indigenous music was originally the indefatigable voice of the masses which has the capacity to penetrate high, low, public and private spaces; to reach out and coerce egalitarian relationships irrespective of wealth and status

Based on this premise, the conclusion that the Nigerian indigenous music has provided the basic foundation on which musical arts education and practice in contemporary Nigeria was drawn. It has, therefore, become imperative to localize the task of planning our educational programmes to reflect in our music curricula at all levels, needs, aspirations, values, problems and trends of our traditional society. It is only by achieving this that Nigerian cultures in musical arts education within the threshold of current global environment would be perpetuated.

*Dan C. C. Agu PhD is a Professor of Ethnomusicology and Music Education in the Department of Music, Nnamdi Azikiwe University, Awka. 
UJAH: Unizik Journal of Arts and Humanities Vol. 13 No 2, 2012

\section{Note}

1. Plan drawn from Nzewi (2003) Objectives and Logic of Musicianship Education in Africa - Acquiring Knowledge of the Musical Arts in Traditional Society.

\section{References}

Agu, D. C. C. (1989). The influence of technology on music creativity and performance in present day Nigeria. In J.E. Nnadi (ed) The humanities in contemporary Nigerian Education - Relevance and methodological options 115 123. College of Education, Eha-Amufu Enugu State

Agu D. C. C. (2008). Advancing music scholarship in Nigerian Contemporary Music theory, pedagogy and creativity. Awka Journal of Research in Music and Arts. (AJRMA). 5, 216-233.

Amamasi, C. (2008). Daily Independent News Paper. H. Aruma (ed) Wednesday $17^{\text {th }}$ September 2008 p.E8

Blacking, J. B. (1971). Music and Historical process in Vendaland. In K.P. Wachsmann (ed).Essays on music and history in Africa.

Blacking, J. B. (1973). How musical is man? Seattle University press.

Emeka, L (2002). Traditional Education in Nigeria. In R. Okafor and L. Emeka (eds). Nigerian Peoples and Culture. Enugu. New Generation Publishers.

Federal Government of Nigeria (1989) Cultural policy of the Federal Republic of Nigeria, Lagos.

Federal Government of Nigeria (1998). National Policy on Education. Lagos N.ER.D.E. Press.

Miller, H. (1972). History of Music. USA Harper and Raw publishers Inc. 
Nzewi, M. (1977). Master Musicians and the music of Ukom, Ese and mgba ensemble in Nigeria, Igbo Society. Ph.D. Thesis Belfast. Queen's University.

Nzewi, M. (1980). Folk Music in Nigeria: A communion. African Music, 6, 1, 6-21.

Nzewi, M. (2003). African Musicianship in the Global Thrust: Redemption for Disorienting Human

Nzewi, M. (2007). Re-searching music education for civic activism. Music Education Research music education for civic activism. Music Education Research, 9:3, 305-321.

Ochrie, E and Emeka, L (2003). Thought systems informing musical arts. In A. Herbst, M. Nzewi and K. Agawu (ed). Musical Arts in Africa; theory, practice and education. University of South Africa. Pretoria pp $38-49$.

Pulse. In S. Leons (ed) Musicianship in the $21^{\text {st }}$ Century: Issues, Trends and Possibilities. Australian Music Centre Grosvenor Place NSW.

Okafor, R.C. (1993). Diminuendo: of receding fields and threatened culture among the Igbo of Nigeria.Paper presented at the International Conference in Environmental Issues. Enugu State University of Technology.

Omibiyi - Obidike (1987). Whither Music Education in Nigeria? Paper presented at the $1^{\text {st }}$ National Conference of Nigerian Association of Music Educators, March 11 - 18. Anambra State College of Education Awka, Nigeria.

Weman, H. (1960). African Music and the Church in Africa: Uppsala. 